\title{
LXI. Remarks on certain properties of barytes in its combination with mineral acids; and on two new salts never before described
}

\section{J. Hume Esq.}

To cite this article: J. Hume Esq. (1803) LXI. Remarks on certain properties of barytes in its combination with mineral acids; and on two new salts never before described, Philosophical Magazine Series 1, 14:56, 357-359, DOI: $10.1080 / 14786440308676215$

To link to this article: http://dx.doi.org/10.1080/14786440308676215

曲 Published online: 18 May 2009.

Submit your article to this journal $\pi$

Џll Article views: 2

Q View related articles $\longleftarrow$ 
This experiment was repeated and varied, at the expenfe of feveral thermometer bulbs; and it appeared that water may be conled down in fuch circumftances, not only to $21^{\circ}$, but to 5 or $6^{\circ}$, without freezing, and that the law of expanfion above mentioned obtains in every part of the fiale from $422^{10}$ to $10^{\prime \prime}$ or below; fo that the denfity of water at $10^{\circ}$ is equal to the denfity at $75^{\circ}$.

LXI. Remarks on certain Properties of Barytes in its Combination witb Mincral Acids; and on two new Salts never before dejcribed. By J. Hu $\mathrm{ME}, E f q \cdot *$

$\mathrm{F}$ ROM a number of experiments I have occafionally made on barytes, but chiefly on it when combined with mineral acids, I have been led to draw fome conclufions and obferve phænomena, which, I believe, have hitherto been either totally unknown, or fo very imperfectly detailed, as, no doubt, to have frequently been a fource of error. This earth, for $I$ am not yet difpofed to clafs it with alkalies, certainly poffeffes peculiar habiludes, or ratber, when compared with thofe of other earths and alkalies, and its own combinations compared with each other, fome fingular anomalies, which I have never yet feen pointed out by chemical writers. Amongft many others, the following appear the molt prominent, and therefore demand firt to be noticed.

t. That fulphate of barytes is completely foluble in fulphuric acid; forming a faline fluid or acidulous filphate, analogous, in fome of its characters, to phofphate of lime and many other falts; with capacity for excefs of acid; decompofable by water alone, which returns it to fimple fulphase; and this falt never has been enumerated by any author.

2. That carbonate of barytes is alfo totally decompofed by, and foluble in, fulphuric acid, forming, of courfe, the fame acidulous fulphate. Refpecting any figure this new falt may put on, I have not yet been able fully to determine; but I ftrongly fufpect it may, under particular circumftances, be made to cryftallize.

3. That nitrate of barytes, not in cryftals only, but even a faturated aqueous folution, is perfectly infoluble in nitrous acid of the ufual fpecific gravity.

4. That carbonate of barytes may entirely be changed into nitrate by nitrous acid in its concentrated ftate. The converfe of this has hitherto been maintained.

* Communicated by the Auther. 
5. That muriate of barytes is virtually infoluble in muriatic acid.

6. That carbonate of barytes may be rendered into muriate by concentrated muriatic acid.

7. This may not appear to be, with propriety, placed after the others; it ought neverthelefs to be named, fince no author has given any account of it. It is, that fulphate of ftrontian has alfo a capacity for fuper-faturation; forming, like No. 1 , an acidulous fulphate in folution, and decompofable by water.

In feveral chemical works, written by very eminent men, I have frequently obferved fome of the above refults very nearly accomplifhed; and have been amazed to find fuch palpable truths had efcaped their notice: yet, on a careful examination of the context, I confers, I could never find a fingle proof that any one of thefe peculiarities of barytes has been known to the full extent as above detailed. In refpect to No. I, there is no mention of an acidulous fulphate nor of fluidity, in an effay, where I expected to find it, written in 1790 by C. Fourcroy *. It may alfo be remarked, that in a more modern work by the fame very excellent chemit, fpeaking of fulphate of barytes, he expreffes himfelf thus: "Il parâit cependant diffoluble par des mojens que la nature nous cacbe encore, puifqu'il eft vifiblement criftallifé par l'eau. On ne peut pas le faire criftallifer artificiellement + ." The fame author had affirmed the perfect infolubility of carbonate of barytes in nitrous (or nitric, for it is not yet de. cided) acid: " L'acide nitrique le plus concentré n'a abfolument aucune action fur le carbonate de barite natif en morceau, ce fel y refte intact abfolument comme dans l'eau f." This is quite contrary to the refult of my experiments, even with little more heat being employed than the common atmofpheric temperature. Indeed, regarding the effect of mineral acids upon the native carbonate of witherite, for it would be unfair, in this place, to fpeak of artificial carbonate, the fame author fums up his opinion in one fentence: "Que les acides ne l'attaquent point $\mathrm{en}$ mafle, et lorfqu' ils font concentrés §." Since no part of this analyfis has yet been re-

* Analy ${ }^{2}$ de Carbonate de Baryte natif, \&c. \$ 3 .

+ Syfteme des Conn. Chimique. - "It, however, appears to be foluble by means which nature fill conicals from us, fince it is evidently cryftallized by water. It cannot be made to cryftallize artificially."

¥ Ibid.. "The moft highly concentrated nitric acid bas abfolutely no action on native carbonate of ba ytes in bits. This falt remains in it abfolutely unatracked, as in water."

$\S$ Analyfe, \&r. $\S 4 .-$ "That the acids do not attack it in a mafs, and when they are concentrated." 
tracted, but, on the contrary, if poffible, more completely confirmed by the author's writings fince that period, I have been lefs fcrupulous in applying thefe quotations to my purpofe. Though another author has, in one folitary fentence, apparently flatly contradicted C. Fourcroy, yet, on a clofer infpection of the work, (2de édition confidirablement augment.e,) which I thould call a tbird edition, it does not appear that any one of thefe habitudes or anomalies has been clearly demonftrated to exift. The fentence is, to fay no more of it, evidently conditional, and no mention made either of concentration or dilution: "Tous les acides minéraux decompofent ce fel," (meaning carbonate de barite*) But my doubts were completely removed, at lealt refpecting what $\mathbf{I}$ have ftated at Nos. 3 and 4 , when I read a whole paget, where we find detailed a molt circuitous procefs for purifying nitrous acid by litharge and nitrate of filver.

I purpofely forbear to mention any method I purfued to accomplifh each combination; as it appears to me to be within the limits of the meaneft capacity, and obvious to every chemift to obtain the fame refults.

No. 10\%, Long Acre,

January 24,1 so 3.

LXII. On the Utility of Pruffiate of Copper as a Pigment By Charles Hatchext, E/q. F.R.S. $\ddagger$

T

$\mathrm{HE}$ accidental difcovery made by Dicnbach of the pigment called Berlin or Pruffian blue, about the year 1710 , and which afterwards was publithed by $\mathrm{W}$ oodward in the Philofophical Tranfactions for 1724, was foon adopted by artifts and manufacturers, fo that in a thort time the great utility of this colour was completely eftablithed: it is therefore remarkable, that but little attention has been fubfequently paid to the colorific properties of the other metallic prutliates.

The experiments made by Mr. Brown with the pruffic lixivium on various metallic folutions do not merit particular attention, as the refults evidently thow that a very large portion of the alkali remained unfaturated with pruffic acid, and thus the effects appeared different when the lixivium was prepared with blood or with mufele $\S$.

Bergman has, however, more accurately examined the pro-

- Analyfe, 8zc. §-7.- "All the mineral acids decompofe this falt."

+ Manuel d'un Cours de Chimie, La Giange.

$\$$ From Journals of the Royal Infitution of Great Britain.

$\$$ Philofopbical Tranfactions 1724, p. 17 .

$$
\mathrm{Z}_{4}
$$

